\title{
MIR20A wt Allele
}

National Cancer Institute

\section{Source}

National Cancer Institute. MIR20A wt Allele. NCI Thesaurus. Code C81896.

The human MIR20A wild-type allele is located in the vicinity of $13 q 31.3$ and is 70 bases in length. This allele, which encodes MIR20A RNA, plays a role in lung, liver and breast cancers, lymphoma and leukemia. 